\title{
Chromosomal Location of Human Genes Encoding Major Heat-Shock Protein HSP70
}

\author{
Gail Singer Harrison ${ }^{1,2}$ Harry A. Drabkin, ${ }^{1,2}$ Fa-Ten Kao, ${ }^{1,3}$ Judith Hartz, ${ }^{1}$ Iris M. Hart, ${ }^{1}$ \\ Ernest H. Y. Chu, ${ }^{4}$ Barbara J. Wu, ${ }^{5}$ and Richard I. Morimoto ${ }^{5}$ \\ ${ }^{\prime}$ Eleanor Roosevelt Institute for Cancer Research, 1899 Gaylord Street, Denver, Colorado 80206; ${ }^{2}$ Division of Medi- \\ cal Oncology, and ${ }^{3}$ Department of Biochemistry, Biophysics and Genetics, University of Colorado Health Sciences \\ Center, 4200 East Ninth Avenue, Denver, Colorado 80262: ${ }^{4}$ Department of Human Genetics, University of Michigan \\ Medical School, 1137 East Catherine Street, Ann Arbor, Michigan 48109; Department of Biochemistry, Molecular \\ Biology and Cell Biology, Northwestern University, 2153 Sheridan Road, Evanston, Illinois 60201
}

Received 3 October 1986-Final 9 December 1986

\begin{abstract}
The HSP7O family of heat-shock proteins constitutes the major proteins synthesized in response to elevated temperatures and other forms of stress. In eukaryotes members of the HSP70 family also include a protein similar if not identical to bovine brain uncoating ATPase and glucose-regulated proteins. An intriguing relation has been established between expression of heat-shock proteins and transformation in mammalian cells. Elevated levels of HSP7O are found in some transformed cell lines, and viral and cellular gene products that are capable of transforming cells in vitro can also stimulate transcription of HSP70 genes. To determine the organization of this complex multigene family in the human genome, we used complementary approaches: Southern analysis and protein gels of Chinese hamster-human somatic cell hybrids, and in situ hybridization to human chromosomes. We demonstrate that functional genes encoding HSP70 proteins map to human chromosomes 6, 14, 21, and at least one other chromosome.
\end{abstract}

\section{INTRODUCTION}

Synthesis of heat-shock proteins in response to stress has been widely observed in prokaryotes and eukaryotes $(1,2)$. Accompanying the rapid induction of heat-shock protein synthesis is a decrease in transcription and translation of other genes and gene products. While the function of these proteins is not clear, there is substantial evidence linking heat-shock proteins with a protective mechanism during and following cellular stress. Furthermore, there is an intriguing relation between expression of heat-shock proteins and malignant transformation in mammalian cells. HeLa cells as well as several other tumor cell lines show elevated levels of expression of the major heat-shock protein, HSP70, at normal temperatures $(3,4)$. Expression of HSP70 is stimulated in mammalian cells by the adenovirus Ela 13 s product and the polyoma virus large $\mathrm{T}$ antigen (5-7); additionally, a rearranged c-myc gene can stimulate expression from a Drosophila HSP70 promoter transfected into Chinese hamster ovary (CHO) cells (8).

The viral-transforming proteins and cellular protooncogenes that stimulate expression of HSP70 have all been implicated in immortalization of primary cells in culture 
(9-11). Thus, immortalizing gene products may effect transcription at cellular promoters to repress or activate expression of genes, including those encoding heat-shock proteins. The significance of the trans-activation of HSP70 gene expression by viral or cellular transforming proteins is further revealed by the growth-regulated expression of human HSP 70 by serum stimulation (4) and during the synthetic phase of the cell cycle $(12,13)$.

There is also evidence that heat-shock proteins and antigens associated with transformation may be physically complexed. Several heat-shock-induced proteins of about 70 kilodaltons (kd) appear to be tightly associated with the p53 cellular antigen in a transformed rat fibroblast line which overexpresses this antigen (14). Furthermore, in a murine chemically induced sarcoma, a tumor-specific transplantation antigen shows considerable homology at the amino acid level to the Drosophila $83-\mathrm{kd}$ heat-shock protein (15). A fundamental role for $H S P 70$ is also suggested by its strong evolutionary conservation from bacteria to man. Furthermore, deletion of this gene in yeast results in impaired growth at normal temperatures (16), implying that $H S P 70$ has an important function independent of its role during stress.

Multiple copies of HSP7O genes have been detected in most organisms, including Drosophila, yeast, mouse, and man (17-19). Members of the human HSP70 gene family have been cloned, using probes from both Drosophila and rat $(20,21)$. This is an extensive gene family with perhaps 10 or more members, only one of which appears to be a pseudogene (20). One member of the human HSP70 family is similar or identical to the constitutively expressed bovine brain uncoating ATPase, involved in release of clathrin from coated vesicles (22).

In this study, we have determined the chromosomal location of the functional human HSP7O genes, using a combination of Southern hybridization analysis, in situ hybridization, and protein gels. We demon- strate that sequences encoding HSP70 proteins are located on human chromosomes 6, 14 , and 21 , and we also present evidence that homologous sequences reside on at least one other chromosome as well.

\section{MATERIALS AND METHODS}

Cell Lines. $\mathrm{UC2}$ is a $\mathrm{CHO}$ cell line defective in the last two steps of pyrimidine synthesis and therefore requires exogenous uridine for growth. GlyB is also a CHO cell line deficient in glycine metabolism. HeLa is a human cervical carcinoma cell line. The following are CHO-human hybrid cell lines: TLUC2/le5 (and segregants TLUC2/le 5c10, TLUC2/le55c4, and TLUC2/le5c9a), TLUC2/12-8, 8;21/GB12, 314b, F55, 706B6A3, and 72532X-6. Table 1 lists the human chromosomes present in these hybrids. The CHO-human hybrids used for the functional assay for HSP70 are listed in Table 2.

TLUC2/le5 and TLUC2/12-8 were constructed from a $\mathrm{t}(3 ; 8)(\mathrm{p} 14.2 ; \mathrm{q} 24.1)$ human lymphoblastoid line, kindly provided by $\mathrm{Dr}$. Tom Glover, fused to $\mathrm{CHO}$ cell line UC2 as previously described (23). These hybrid cell lines selectively retain the long arm of human chromosome 3 (in this case, a $3 \mathrm{p}^{-}$chromosome) which supplies the uridine requirement for the parent UC2 cells. In TLUC2/le5, $100 \%$ of the cells have the $3 \mathrm{p}^{-}$chromosome, approximately $90 \%$ have chromosome 6 , and 90\% have the CHO human translocation. The presence of the human marker chromosome is more variable, appearing in $10-50 \%$ of the cells. In the segregants of TLUC2/le5, the chromosome constitution as described in Table 1 exists in nearly $100 \%$ of the cells examined.

$8 ; 21$ GB12 contains a normal chromosome 8 as the only human material isolated from $\mathrm{t}(8 ; 21)$ acute myleogenous leukemia cells. $314 \mathrm{~b}$, provided by Dr. Carol Jones, contains a normal chromosome 3 as the only human material; 706B6A3 and F55 both contain a normal chromosome 14 as the only 


\begin{tabular}{|c|c|c|c|c|c|c|}
\hline \multirow[b]{2}{*}{ Cell line } & \multirow[b]{2}{*}{ Human chromosomes } & \multicolumn{5}{|c|}{ BamHI-HindIII fragments $(\mathrm{kb})$} \\
\hline & & 7.8 & 5.7 & 3.1 & 2.5 & 2.3 \\
\hline HeLa & full complement & + & + & + & + & + \\
\hline UC2 and GlyB & none & - & - & - & - & - \\
\hline TLUC2/le5 & $3 \mathrm{p}-; 6 ; \mathrm{T} ; \mathbf{M}^{\alpha}$ & + & + & - & + & - \\
\hline TLUC2/le $5 \mathrm{c} 10$ & $3 \mathrm{p}-; 6 ; \mathrm{M}$ & + & + & - & + & - \\
\hline TLUC2/le55c4 & $3 \mathrm{p}-; 6 ; \mathrm{T}$ & + & + & - & + & - \\
\hline TLUC2/le5c9a & $3 \mathrm{p}-; \mathrm{T} ; \mathrm{M}$ & - & - & - & - & - \\
\hline TLUC2/12-8 & $3 \mathrm{p}-$ & - & - & - & - & - \\
\hline $8 ; 21 / \mathrm{GB} 12$ & 8 & - & - & - & - & - \\
\hline $314 b$ & 3 & - & - & - & - & - \\
\hline $72532 X-6$ & 21 & - & - & - & - & - \\
\hline $706 \mathrm{~B} 6 \mathrm{~A} 3$ & 14 & - & - & - & + & - \\
\hline
\end{tabular}

human material, and $72532 \mathrm{X}-6$, kindly provided by Dr. David Patterson, contains a normal chromosome 21 as the only human material.

A panel of human-Chinese hamster somatic cell hybrid clones (Table 2) was used to determine the chromosomal assignment of functional HSP70 genes, as assayed by protein gels. Some of the hybrids were derivatives of previously described hybrids and their chromosome content has recently been characterized. All hybrids were cultured in F12 or F12D media supplemented with $6-10 \%$ fetal calf serum.

Identification of Human Chromosomes in Hybrid Cell Lines. Human chromosomes were identified cytogenetically by Giemsatrypsin (GTG) banding and sequential Giem-

Table 2. Expression of HSP70 by Protein Polymorphisms and Analysis by Two-Dimensional Gel Electrophoresis

Human chromosome

\begin{tabular}{|c|c|c|c|c|c|c|c|c|c|c|c|c|c|c|c|c|c|c|c|c|c|c|c|c|}
\hline & \multicolumn{24}{|c|}{ Human chromosome } \\
\hline & 1 & 2 & 3 & 4 & 5 & 6 & 7 & 8 & 9 & 10 & 11 & 12 & 13 & 14 & 15 & 16 & 17 & 18 & 19 & 20 & 21 & 22 & $\mathrm{X}$ & HSP70 \\
\hline CP 3-2 & - & - & - & + & + & - & - & - & - & - & + & + & - & - & - & + & - & + & + & + & - & - & + & - \\
\hline CP 5-1 & + & - & - & - & + & - & - & + & + & - & - & + & - & + & + & - & + & - & + & - & + & + & - & + \\
\hline CP 6-1 & - & - & - & + & - & - & - & - & - & - & - & + & - & + & - & - & + & + & + & - & + & + & - & + \\
\hline CP $11-2$ & - & - & - & - & + & - & - & - & - & - & - & - & - & - & - & - & - & + & + & - & - & - & - & - \\
\hline CP 12-1 & - & + & - & + & - & - & - & + & + & + & + & + & + & - & - & - & - & - & - & - & + & + & + & + \\
\hline CP 14-2 & - & - & - & + & + & - & - & - & - & - & - & - & - & + & - & - & + & - & - & - & - & + & + & + \\
\hline CP $15-2$ & - & - & - & + & + & - & - & - & - & - & + & + & - & + & + & + & + & - & - & - & - & - & - & + \\
\hline CP 16-1 & - & - & - & - & + & - & - & - & - & - & - & - & - & + & - & - & + & - & + & + & + & + & - & + \\
\hline CP $18-1$ & + & - & - & - & - & - & - & + & - & -- & + & - & - & + & + & - & + & + & + & - & - & - & - & + \\
\hline CP 20-1 & - & + & - & - & + & - & - & - & + & -- & - & - & - & - & - & - & + & - & - & - & + & - & - & + \\
\hline CP 22 & - & - & - & - & - & - & - & - & - & - & - & - & -. & - & + & - & - & - & - & - & + & - & - & + \\
\hline CP 26-2 & + & - & - & + & + & + & + & - & + & + & + & + & + & + & - & - & + & - & - & - & - & - & - & + \\
\hline CP 27 & - & + & + & + & + & + & + & - & - & - & - & + & + & + & - & + & - & + & - & - & + & - & + & + \\
\hline CP 28 & + & - & + & + & + & + & - & - & + & - & - & - & - & - & - & + & - & + & + & + & + & + & - & + \\
\hline CP $38-1$ & - & - & - & - & - & - & - & - & + & - & - & - & - & - & - & - & - & - & - & - & + & - & - & + \\
\hline CP 23 & - & - & - & - & - & - & - & - & - & -- & - & - & - & + & - & - & + & - & - & - & - & - & - & + \\
\hline CP 23-4-1 & - & - & - & - & - & - & - & - & - & - & - & - & - & - & - & - & + & - & - & - & - & - & - & - \\
\hline CP 43 & - & - & - & - & - & - & - & - & - & - & - & - & - & + & - & - & - & - & - & - & - & - & - & + \\
\hline CP 43-1 & - & - & - & - & - & - & - & - & - & - & - & - & - & - & - & - & - & - & - & - & - & - & - & - \\
\hline CP72532X-6 & - & - & - & - & - & - & - & - & - & - & - & - & - & - & - & - & - & - & - & - & + & - & - & + \\
\hline TLUC2/le5 & - & - & + & - & - & + & - & - & - & - & - & - & - & - & - & - & - & - & - & - & - & - & - & + \\
\hline TLUC2/le 5c9a & - & - & + & - & - & - & - & - & - & - & - & - & - & - & - & - & - & - & - & - & - & - & - & - \\
\hline
\end{tabular}


sa-11 staining (24). Additionally, R-banding (RHG) was done on TLUC2/le5 and its segregant lines to further confirm the identification of human chromosomes (25).

In addition to cytogenetic analysis, the presence of chromosome 14 in cell lines F55 and $706 \mathrm{~B} 6 \mathrm{~A} 3$ was verified by performing in isozyme assay for nucleoside phosphorylase activity using Cellogel electrophoresis (26). The presence of chromosome 6 in cell line TLUC2/le5 (and its segregants) was verified by Southern hybridization using the human chromosome 6-specific MHC probe, DRalpha, kindly provided by Drs. Thomas Spies and Jack Strominger.

DNA Isolation and Molecular Probes. The probe $\mathrm{pH} 2.3$, which contains the entire DNA sequence coding for a human heat-shock protein of about $70 \mathrm{kd}$ has been previously described (21). High-molecularweight DNA was prepared (27), and digested with approximately 5 units of the appropriate restriction enzyme per $\mu \mathrm{g}$ of DNA for at least $4 \mathrm{hr}$ at $37^{\circ} \mathrm{C}$. The digested DNA was electrophoresed in a horizontal $0.8 \%$ agarose gel in Tris-acetate buffer. HindIII-digested phage lambda DNA was used for molecular weight markers.

Southern Analysis. Transfer of DNA to nitrocellulose paper was performed using the method of Southern (28). Filters were prehybridized overnight at $42^{\circ} \mathrm{C}$ in $5 \times \mathrm{SSC}$ (SSC $=150 \mathrm{mM} \mathrm{Na}$ chloride, $15 \mathrm{mM} \mathrm{Na}$ citrate), $5 \times$ Denhardt solution (Denhardt solution $=0.02 \%$ each of Ficoll, polyvinylpyrolidone, and bovine serum albumin), 45\% formamide, and $500 \mu \mathrm{g} / \mathrm{ml}$ of salmon sperm DNA. Hybridization was performed at $42^{\circ} \mathrm{C}$ overnight in $5 \times \mathrm{SSC}, 1 \times$ Denhardt solution, $10 \%$ dextran sulfate, $45 \%$ formamide, 100 $\mu \mathrm{g} / \mathrm{ml}$ of salmon sperm DNA, and $0.5 \%$ SDS. The filters were washed with $2 \times \mathrm{SSC}, 0.1 \%$ SDS at room temperature followed by washing at $55^{\circ} \mathrm{C}$ in $0.1 \times \mathrm{SSC}, 0.1 \%$ SDS. Filters were used to expose Kodak XAR-5 film for periods of $5 \mathrm{~h}$ to several days.

In Situ Hybridization. In situ hybridization was similar to that of Harper and
Saunders (29). Human chromosomes were prepared from phytohemagglutinin-stimulated peripheral blood lymphocytes synchronized with methotrexate and thymidine and incubated with colcemid $(0.1 \mu \mathrm{g} / \mathrm{ml})$ for 10 min prior to harvest. Slides were treated with RNase $(100 \mu \mathrm{g} / \mathrm{ml})$ for $1 \mathrm{~h}$ at $37^{\circ} \mathrm{C}$, rinsed in $2 \times \mathrm{SSC}$, and dehydrated in ethanol. The chromosomes were denatured in $70 \%$ formamide, $2 \times \mathrm{SSC}$ at $70^{\circ} \mathrm{C}$ for $2 \mathrm{~min}$, and then dehydrated in ethanol. The probe was labeled by nick translation with $\left[{ }^{3} \mathrm{H}\right] \mathrm{dCTP}$, $\left[{ }^{3} \mathrm{H}\right] \mathrm{dTTP}$, and $\left[{ }^{3} \mathrm{H}\right] \mathrm{dATP}$ to a specific activity of approximately $1.7 \times 10^{7} \mathrm{cpm} / \mu \mathrm{g}$ of DNA.

The hybridization was carried out at $37^{\circ} \mathrm{C}$ for $18 \mathrm{~h}$ in $50 \%$ formamide, $10 \%$ dextran sulfate, $2 \times$ SSCP $(\mathrm{SSCP}=0.12 \mathrm{M} \mathrm{Na}$ chloride, $0.015 \mathrm{M} \mathrm{Na}$ citrate, $0.02 \mathrm{M} \mathrm{Na}$ phosphate), $1 \mathrm{mg} / \mathrm{ml}$ salmon sperm DNA, and $1 \times$ Denhardt solution. After hybridization, the slides were washed extensively in $50 \%$ formamide $-2 \times$ SSC at $41^{\circ} \mathrm{C}$, then in $2 \times \mathrm{SSC}$ at $41^{\circ} \mathrm{C}$ and at room temperature, followed by dehydration in ethanol and air drying. Slides were coated with Kodak NTB-2 nuclear track emulsion, stored at $4^{\circ} \mathrm{C}$ for 7,10 , or 14 days and developed in Kodak Dektol. The slides were stained with Wright's stain or with Fisher's Giemsa stain in phosphate buffer at $\mathrm{pH}$ 6.8 .

$\left[^{35}\right.$ S/Methionine Labeling and Gel Electrophoresis. Cells were exposed to $43^{\circ} \mathrm{C}$ for 1 (heat shock) or maintained at $37^{\circ} \mathrm{C}$ (control) prior to in vivo pulse labeling with $10 \mu \mathrm{Ci} / \mathrm{ml}$ of $\left[{ }^{35} \mathrm{~S}\right]$ methionine (Amersham) at $37^{\circ} \mathrm{C}$ for 1 $h$. The proteins were analyzed by two-dimensional gel electrophoresis (30) using $\mathrm{pH} 5-7$ ampholines (LKB) and the gels were processed by fluorography (31).

\section{RESULTS}

Localization and Organization of HSP70 Sequences on Specific Human Chromosomes. We have used the human HSP70 DNA clone, plasmid pH2.3, to probe DNA isolated from $\mathrm{CHO}$-human somatic cell 
hybrids (Table 1) in order to determine the chromosomal location of this as well as other homologous HSP7O gene sequences. $\mathrm{pH} 2.3$, a 2.5-kilobase $(\mathrm{kb})$ BamHI-HindIII fragment, has been shown to contain the entire coding region for a heat-shock-induced protein of 70 $\mathrm{kd}$ and hybridizes to a polyadenylated message of $2.6 \mathrm{~kb}(21)$. The sequences within $\mathrm{pH} 2.3$ are repeated in the human genome and show homology to a number of BamHIHindIII fragments in DNA from HeLa cells. These fragments, at 7.8, 5.7, 3.1, 2.5, and 2.3 $\mathrm{kb}$, are seen in Fig. $1 A$, lane b. Judging from the intensity and size of the fragment at 2.5 $\mathrm{kb}$, we believe this to be homologous to the cloned sequence. The BamHI-HindIII fragments from CHO DNA homologous to $\mathrm{pH} 2.3$ were detected at $12.5,8.2,3.5$, and $2.8 \mathrm{~kb}$, with faint bands also visible at 4.6 and $4.8 \mathrm{~kb}$ (Fig. $1 A$, lane a). These $\mathrm{CHO}$ fragments are seen as a constant reference in DNA from all the CHO-human somatic hybrids.

In our approach to mapping $H S P 70$ sequences by Southern hybridization, we focused on chromosomes we believed, by data to be presented later, to have sequences homologous to $\mathrm{pH} 2.3$. Hybridization of $\mathrm{pH} 2.3$ to BamHI-HindIII-digested DNA from CHO-human somatic hybrids is shown in Fig. $1 A$, lanes c-f, and Fig. $1 B$. The hybrid cell line TLUC2/le 5 contains human chromosome 6 , a $3 \mathrm{p}$-chromosome resulting from a human 3;8 translocation previously described (23), a small fragment of human material translocated onto a CHO chromosome (designated " $T$ ") and a metacentric group E-sized human marker chromosome (designated "M"). Hybridization of $\mathrm{pH} 2.3$ to DNA from TLUC2/le5 is seen in Fig. $1 A$,, lane c. The human fragments were detected at $7.8,5.7$, and $2.5 \mathrm{~kb}$.

In order to determine which human material in TLUC2/le5 contained sequences homologous to $\mathrm{pH} 2.3$, we isolated three segregants, each of which had lost a different human chromosomal element. Hybridization of $\mathrm{pH} 2.3$ to BamHI-HindIII-digested DNA from these segregants is seen in Fig. $1 B$. In
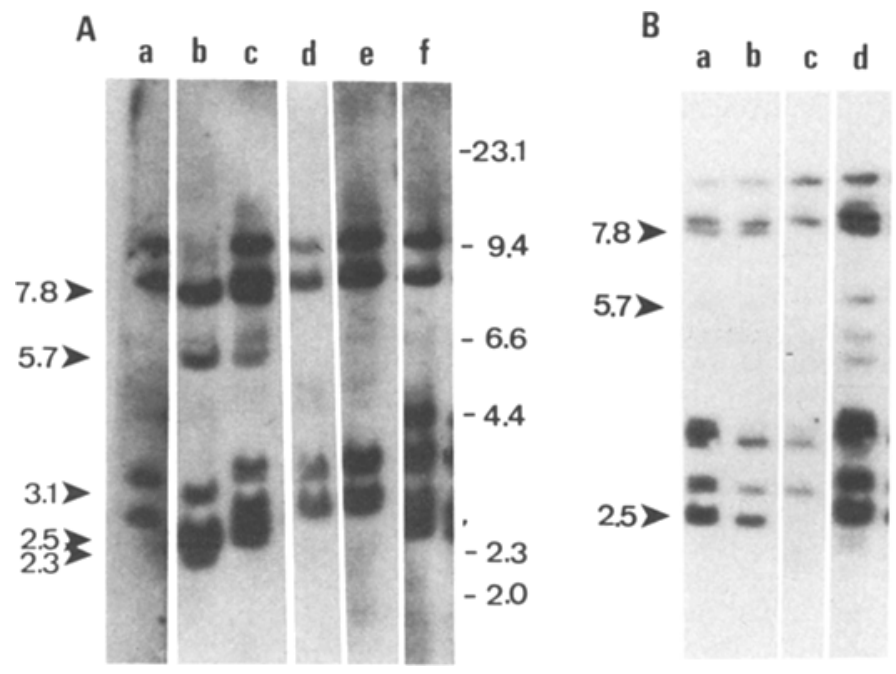

Fig. 1. (A) Hybridization of $\mathrm{pH} 2.3$ to BamHI-HindIII-digested DNA from UC2 CHO cells (lane a); HeLa cells (lane b); and hybrid cell lines TLUC2/le5 (lane c), TLUC2/12-8 (lane d), 8;21/GB12 (lane e), and 706B6A3 (lane f). The size of the $\mathrm{CHO}$ and human bands was estimated by running phage lambda DNA digested with HindIII; migration of the lambda standard is shown at the right margin. Arrows at the left margin indicate human fragments. The band seen just above the 3.5-kb CHO band in lane $\mathrm{f}$ was shown to be a plasmid contaminant in this DNA preparation by hybridization with pBR325. (B) Hybridization of $\mathrm{pH} 2.3$ to BamHI-HindIII-digested DNA from segregants of TLUC2/le5: TLUC2/le55c4 (lane a), TLUC2/le 5c10 (lane B), TLUC2/le5c9a (lane c), and a longer exposure of lane a (lane d). 
TLUC2/le55c4, which has lost the metacentric marker, human fragments were detected at $7.8,5.7$, and $2.5 \mathrm{~kb}$ (Fig. $1 B$, lane a). A longer exposure is shown in lane $\mathrm{d}$, in which the $5.7-\mathrm{kb}$ fragment is more evident. The same fragments at $7.8,5.7$, and $2.5 \mathrm{~kb}$ were also seen in DNA from segregant TLUC2/ le $5 \mathrm{c} 10$ which has lost the $\mathrm{CHO}$-human translocation chromosome (Fig. $1 B$, lane b). Thus, the human fragments $\mathrm{T}$ and $\mathrm{M}$ do not contain sequences homologous to the $\mathrm{pH} 2.3$ probe. In contrast, no human fragments were detected by $\mathrm{pH} 2.3$ in DNA from TLUC2/le5c9a which has lost chromosome 6 but retained the $3 \mathrm{p}$ - chromosome as well as the $\mathrm{T}$ and $\mathrm{M}$ fragments (Fig. $1 B$, lane c). This conclusively demonstrates the three fragments at 7.8, 5.7, and $2.5 \mathrm{~kb}$ all map to chromosome 6 . Only the 2.5-kb BamHI-HindIII fragment is located on the original human genomic clone H3-1 (21). Therefore, the 7.8 - and $5.7-\mathrm{kb}$ fragments are likely to correspond to additional HSP70 gene sequences on chromosome 6 .

None of the human fragments were detected in DNA from hybrids TLUC2/12-8 which contains the $3 \mathrm{p}$ - chromosome as the only identifiable human material, or in $8 ; 21$ / GB12 which contains chromosome 8 as the only human material (Fig. 1 A, lanes $\mathrm{d}$ and e). The same is true for hybrids $314 \mathrm{~b}$ and $72532 \mathrm{X}-6$, which contain chromosomes 3 and 21 , respectively, as the only human material (not shown). Although sequences homologous to $\mathrm{pH} 2.3$ were not detected on chromosome 21 by this analysis, we will demonstrate (Fig. 6 and Table 2) that a heat-shock-induced protein does indeed localize to chromosome 21.

The assignment of HSP7O sequences to human chromosome 14 is demonstrated in Fig. $1 A$, lane f. Hybridization of $\mathrm{pH} 2.3$ to DNA from cell line 706B6A3, which has chromosome 14 as the only human material, reveals a human fragment at $2.5 \mathrm{~kb}$ only (the band just above the CHO $3.5-\mathrm{kb}$ fragment, which does not correspond to either a $\mathrm{CHO}$ or human fragment, was shown to be a plasmid contaminant by hybridization with pBR325). The same human $2.5-\mathrm{kb}$ fragment was observed in another cell hybrid, F55, which also had number 14 as the only human material (not shown).

Thus, sequences hom ologous to $\mathrm{pH} 2.3$ reside on chromosome 14 as well as on chromosome 6 . The data are summarized in Table 1, and Giemsa-trypsin banding and R-banding of chromosomes from the relevant hybrid cell lines is shown in Fig. 2. Members of this multigene family appear to be highly conserved, since all the BamHI-HindIII fragments were stable even after a $65^{\circ} \mathrm{C}$ wash in $0.1 \times$ SSC.

Additional HSP7O sequences were detected in the BamHI-HindIII digestion at 3.1 and $2.3 \mathrm{~kb}$ in total human DNA (Fig. $1 A$, lane b), but these were not present in DNA from any of the hybrids already examined. Thus, these sequences must reside on a chromosome other than 6 or 14 (or 3,8 , and 21), indicating that there is a minimum of three chromosomes in the human genome coding for sequences homologous to $\mathrm{pH} 2.3$. Additionally, there may be genes coding for 70-kd heatshock proteins (or pseudogenes) which are not sufficiently homologous to the probe to be detected by Southern hybridization analysis.

We attempted to distinguish between the HSP70 sequences on chromosomes 6 and 14 by digestion with different restriction enzymes, since a 2.5-kb BamHI-HindIII fragment homologous to $\mathrm{pH} 2.3$ was mapped to both chromosomes. Figure 3, lane a, shows the probe $\mathrm{pH} 2.3$ hybridized to EcoR1-digested DNA from HeLa cells. The major fragments were at $20.0,5.2,4.0$, and $3.3 \mathrm{~kb}$ (the faint fragment above the $5.2-\mathrm{kb}$ fragment was not reproducible; this may be a partial digestion product or a less homologous sequence variably detected). The major CHO fragments, present in DNA from all the hybrid cell lines, were at $17.5,8.5,5.3$, and 4.3 , with faint fragments at 7.0, 5.8, 3.4, 3.0, and $2.5 \mathrm{~kb}$ (Fig. 3 , lane b). The CHO fragment at $8.5 \mathrm{~kb}$ was consistently more intense in this $\mathrm{CHO}$ cell line, GlyB, than in another $\mathrm{CHO}$ cell line, UC2 (not shown); this may represent a polymorphism or amplification. 

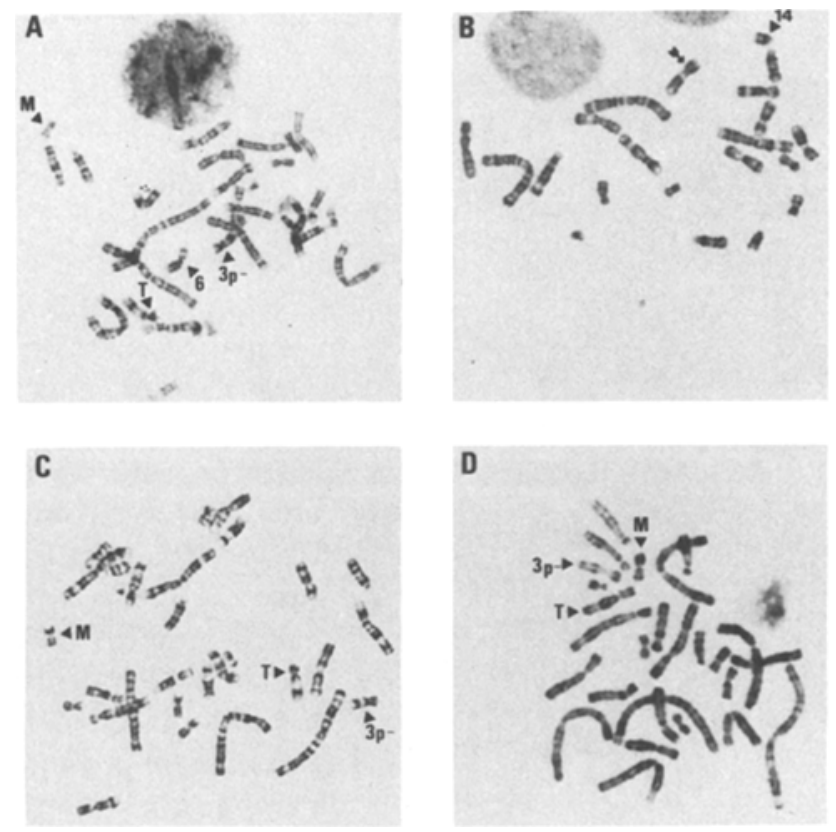

Fig. 2. G-banding (GTG) of chromosomes from TLUC2/le5 (A) and 706B6A3 (B); G-banding and R-banding (RHG) of chromosomes from TLUC2/le 5c9a (C, D) demonstrate the absence of chromosome 6 in this segregant. " $M$ " refers to a human metacentric marker, and " $\mathrm{T}$ " refers to a $\mathrm{CHO}$-human translocation chromosome. The arrow in panel $\mathrm{B}$ points to a second human chromosome 14 translocated onto a $\mathrm{CHO}$ chromosome.

Hybridization of $\mathrm{pH} 2.3$ to DNA from segregant cell lines TLUC2/le $55 \mathrm{c} 4$ and TLUC2/le $5 \mathrm{c} 10$ is seen in Fig. 3, lanes $\mathrm{c}$ and d. The only human fragment apparent was at approximately $20 \mathrm{~kb}$. The intensity of the $20-\mathrm{kb}$ fragment suggests that it contains the sequence homologous to the cloned gene; this is consistent with assignement of the cloned gene to chromosome 6 by the analysis of the BamHI-HindIII digestion shown in Fig. 1. While the human $4.0-$ and $3.3-\mathrm{kb}$ fragments were clearly absent in these DNAs, it is more difficult to determine if the 5.2-kb human fragment is also absent because this fragment comigrates with the $\mathrm{CHO}$ fragment at $5.3-\mathrm{kb}$ (compare lanes a and b in Fig. 3). However, triple digestion of DNA from either HeLa cells or TLUC2/le 5 with EcoR1, BamHI, and HindIII generated the same pattern upon hybridization with $\mathrm{pH} 2.3$ as digestion with BamHI and HindIII alone (not shown). This supports the notion that the EcoR 1 sites are outside the BamHI-HindIII sites and that all the BamHI-HindIII fragments (at 7.8, 5.7, and $2.5 \mathrm{~kb}$ ) mapped to chromosome 6 reside within the single $20-\mathrm{kb}$ EcoR 1 fragment. We suggest that the $20-\mathrm{kb}$ EcoR 1 fragment containing three BamHI-HindIII fragments homologous to the HSP70 gene overlaps with the genomic clone $\mathrm{H} 3-1$ which has a single EcoR 1 site within the insert.

Hybridization of $\mathrm{pH} 2.3$ to DNA from TLUC2/le5c9a (which has lost chromosome 6 ) is seen in Fig. 3, lane e. As expected, the 20.0-kb human fragment was absent, again confirming the localization of sequences homologous to the probe $\mathrm{pH} 2.3$ on chromosome 6. In DNA from cell line 706B6A3, a single human fragment was detected at $3.3 \mathrm{~kb}$ (Fig. 3, lane f). Thus, the EcoR 1 fragments homologous to $\mathrm{pH} 2.3$ in DNA from TLUC2/ le 5 and $706 \mathrm{~B} 6 \mathrm{~A} 3$, corresponding to chromosomes 6 and 14, respectively, are distinct.

Regional Mapping of HSP70 Sequences. To further localize the region on chromosomes 6 and 14 where the heat-shock 


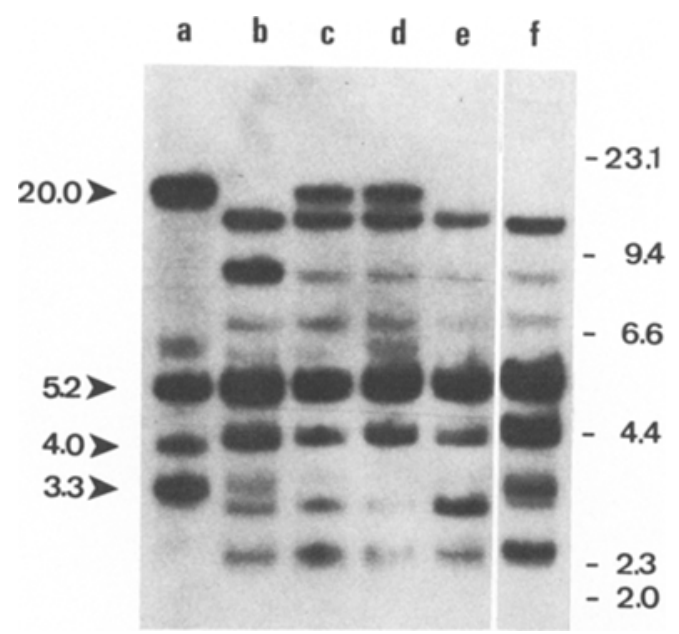

Fig. 3. Hybridization of $\mathrm{pH} 2.3$ to EcoR1-digested DNA from HeLa cells (lane a) and GlyB CHO cells (lane b), and hybrid cell lines TLUC2/le55c4 (lane c), TLUC2/ le $5 \mathrm{c} 10$ (lane d), TLUC2/le $5 \mathrm{c} 9 \mathrm{a}$ (lane e), and 706B6A3 (lane f).

genes reside, we performed in situ hybridization with $\mathrm{pH} 2.3$ to human chromosomes. Figure 4 shows the grain distribution over chromosomes 6 and 14 from 57 human chromosome spreads, with low background (mostly 1-3 grains per spread). A total of 98 grains were found in 28 spreads that had grains on chromosome 6. Among 45 grains located on chromosome $6,80 \%(36 / 45)$ were localized in the region $\mathrm{p} 21-\mathrm{p} 23$ with a peak in p21.3-p22. For chromosome 14, 32 grains were found in 25 spreads that had grains on this chromosome. The grains were largely clustered in the region q22-q24 with a peak in q22.

Functional Analysis by HSP70 Protein Polymorphism. The assay we have used to detect the presence of a human HSP7O gene in the somatic cell hybrids relies on differences in the electrophoretic mobilities of human HSP70 and hamster HSP72 as revealed by one and two dimensional gel electrophoresis. HeLa and $\mathrm{CHO}$ cells were exposed to $43^{\circ} \mathrm{C}$ for $1 \mathrm{~h}$ (heat shock) or maintained at $37^{\circ} \mathrm{C}$ (control) prior to in vivo pulse labeling with $\left[{ }^{35} \mathrm{~S}\right]$ methionine at $37^{\circ} \mathrm{C}$ for $1 \mathrm{~h}$. The proteins were analyzed by both one- and two-dimensional gel electrophoresis, and the gels were processed by fluorography. Human HSP70 is clearly distinct in electrophoretic mobility and apparent isoelectric point from the hamster HSP72 (Fig. 5). Indeed, the differences remain in a mixture of lysates prepared from heat-shock hamster and human cells (Fig. 5) and therefore should be apparent in somatic cell hybrids.

The method for mapping the chromosome location of the human HSP70 gene was to examine the $\left[{ }^{35} \mathrm{~S}\right]$ methionine-labeled proteins synthesized in a panel of cell hybrids
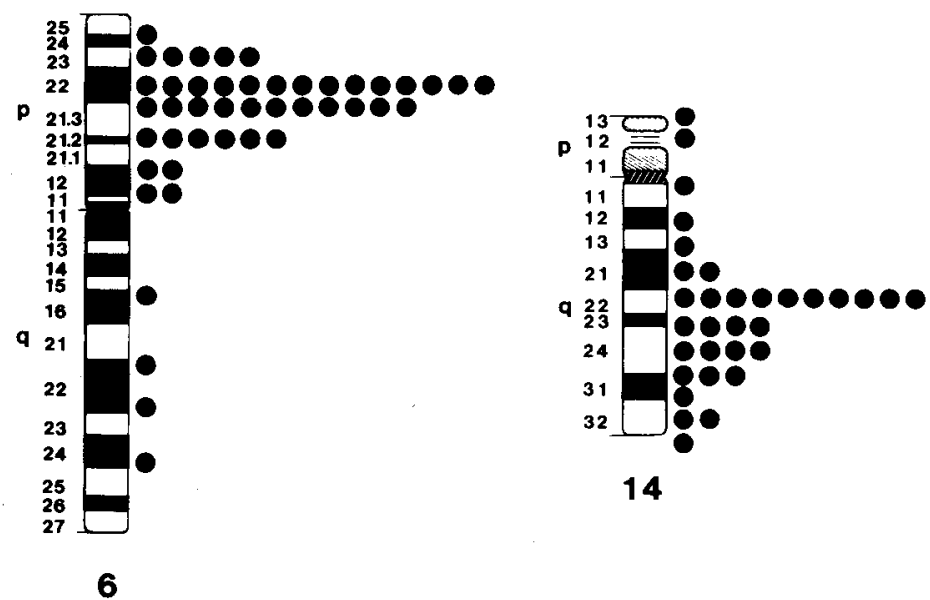

Fig. 4. Analysis of grain distribution on chromosomes 6 and 14 by in situ hybridization to 57 chromosome spreads, using the probe $\mathrm{pH} 2.3$. 
Hu
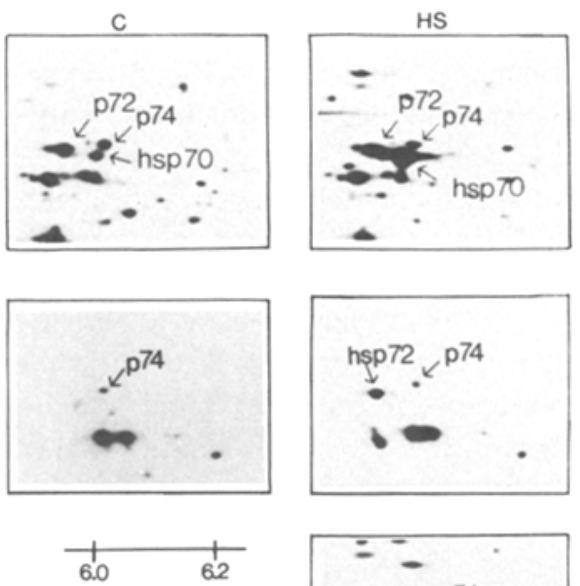

$\operatorname{Mix}$
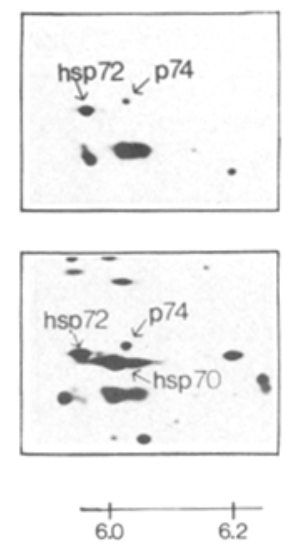

Fig. 5. Autofluorogram of the $\left[{ }^{35} \mathrm{~S}\right]$ methionine-labeled proteins synthesized in $\mathrm{HeLa}(\mathrm{Hu})$ and Chinese hamster ovary (Ha) cells maintained at $37^{\circ} \mathrm{C}(\mathrm{C})$ or exposed to $43^{\circ} \mathrm{C}$ (HS) for $1 \mathrm{hr}$. The cells were incubated at $37^{\circ} \mathrm{C}$ for $1 \mathrm{~h}$ with $10 \mu \mathrm{Ci} / \mathrm{ml}\left[{ }^{35} \mathrm{~S}\right]$ methionine. The proteins were analyzed by two-dimensional gel electrophoresis using $\mathrm{pH}$ 5-7 ampholines in the first dimension. The $\mathrm{pH}$ gradient of the isofocusing gel is as indicated. A mixture (mix) of cell lysates from heat-shocked HeLa and Chinese hamster ovary cells was similarly analyzed. Marker proteins (p) and heat-shock-induced proteins (hsp) are indicated by arrows and molecular weights given in kilodaltons.

chosen because of their unique combinations of human chromosomes. We analyzed the proteins synthesized in control and heatshocked samples of over 20 hybrids (Table 2), and the results of selected hybrids are shown in Fig. 6. For example, CP22, synthesizes a heat-shock-inducible human HSP70 while hybrid CP11 does not. To demonstrate that the cells have been heat shocked, an internal control is provided by the induced synthesis of hamster HSP72.

Data from the initial panel of somatic cell hybrids suggested that there were two HSP70 loci. Syntenic analysis (Table 2), the positive association (concordant segregation) of a gene and a chromosome, suggested that there may be two nonallelic HSP70 loci.
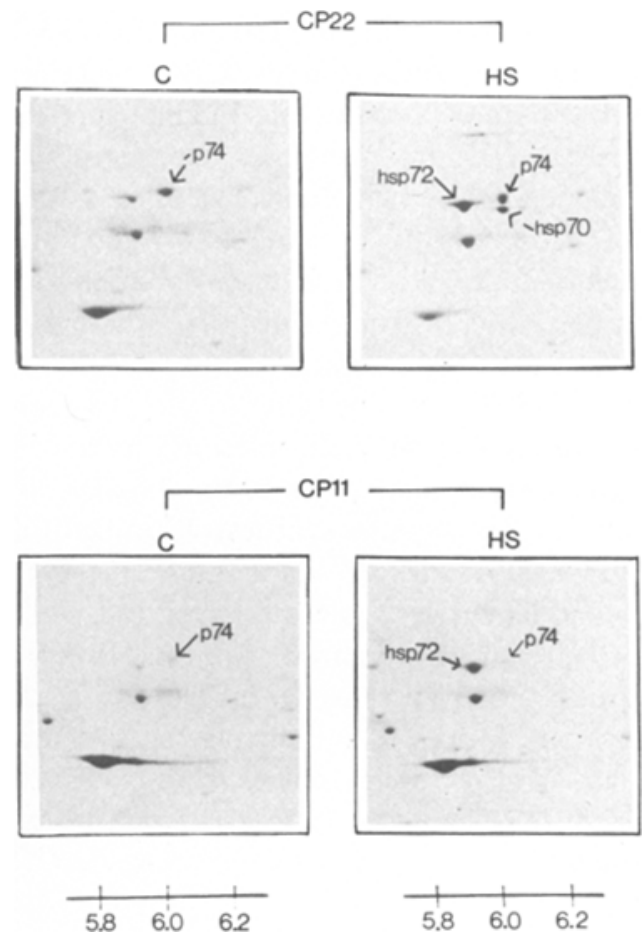

Fig. 6. Autofluorogram of the in vivo labeled proteins synthesized in cloned human-hamster somatic cell hybrids CP22 and CP11 under control (C) or heat-shock (HS) conditions. The cells were incubated with $\left[{ }^{35} \mathrm{~S}\right] \mathrm{me}-$ thionine and the proteins were analyzed by two-dimensional gel electrophoresis.

Although no chromosome segregated perfectly with $H S P 70$, three chromosomes have high concordances: chromosomes 14,17 , and 21 . We then used hybrids containing very few human chromosomes for a more definitive assignment. In particular, CP22 contained only two human chromosomes, 15 and 21 . CP38-1 contained two human chromosomes, 9 and 21, and CP72532X-6 contained only human chromosome, 21 (Table 2). All three hybrids expressed human $H S P 70$ following heat-shock suggesting that a HSP7O gene resides on chromosome 21 . In addition, CP23 contained two human chromosomes, 14 and $17 \mathrm{q}$ (including the entire long arm of chromosome 17 translocated to a hamster chromosome), and expressed human HSP7O following heat shock. A subclone from this hybrid, CP23-4-1, which has lost chromosome 14 but 
retained $17 \mathrm{q}$, failed to express human $H S P 70$ following heat shock. Finally, CP43 contained a single human chromosome 14 and expressed human HSP70 following heat shock, whereas subclone CP43-1, which has lost chromosome 14, failed to express human HSP7O upon heat shock (Table 2). These data indicate that another HSP70 gene resides on chromosome 14. The high concordance of chromosome 17 with HSP70 may be due to the frequent positive association of chromosomes 14 and 17 in the clone panel of hybrids. Finally, we analyzed the proteins synthesized in cell line TLUC2/le5 that has human chromosomes $3 \mathrm{p}^{-}$and 6 (Table 1) and a subclone, TLUC2/ le $5 \mathrm{c} 9 \mathrm{a}$, that has lost chromosome 6. HSP70 is synthesized only in the parent and not in the subclone. These data indicate that a functional HSP7O gene, corresponding to the cloned HSP70 gene, is located on chromosome 6.

\section{DISCUSSION}

We have assigned genes that encode the human 70 -kd heat-shock-induced proteins to human chromosomes 6,14 , and 21 by physical mapping of sequences homologous to the cloned human $H S P 70$ gene, $\mathrm{pH} 2.3$, and by a functional assay that detects the synthesis of human HSP70. It appears that there are additional sequences homologous to this probe on at least one other chromosome as well. Our finding that inducible $H S P 70$ sequences exist on multiple chromosomes in the human genome is similar to the findings in other organisms including Drosophila, Xenopus, and mouse (reviewed in reference 1 ).

The cloned BamHI-HindIII fragment, $\mathrm{pH} 2.3$, contains the entire gene coding for a 70-kd heat-shock protein (21), but we have mapped three BamHI-HindIII fragments hybridizing to $\mathrm{pH} 2.3$ to chromosome 6 (one of which we believe to be homologous to the cloned sequence). Thus, there appear to be multiple genes homologous to $\mathrm{pH} 2.3$ on chromosome 6 . We present evidence that these genes are clustered within a 20-kb EcoR 1 fragment. The heat-shock-induced protein on chromosome 21 was detected only by the functional assay and does not appear to be sufficiently homologous to the probe $\mathrm{pH} 2.3$ to be detected by Southern or in situ hybridization analysis.

Regional mapping by in situ hybridization further localized the heat shock gene family on chromosomes 6 and 14. The majority of grains are localized on the short arm of chromosome 6 , with a peak in the region p21.3-p22. If our interpretation of the clustering of the three bands on a 20-kb EcoR l fragment is correct, these bands may all reside in this region.

In view of the putative relation between expression of heat-shock proteins and transformation, it is of interest that the region on chromosome 6 , where the heat-shock sequences are localized, is also involved in a 6;9 translocation seen in acute myelogenous leukemia (32). Furthermore, the human homolog of pim, an oncogene which is activated in murine $\mathrm{T}$-cell lymphomas upon retroviral integration, has recently been mapped to $6 \mathrm{p} 21$ (33), although it is not yet known whether this oncogene is involved in the translocation. The region $6 \mathrm{p} 21$ is also significant because the $H L A$ locus maps here $(34,35)$ and a heritable fragile site has been described at the region 6 p23 (36). The presence and severity of some diseases, such as diabetes, multiple sclerosis, and myasthenia gravis, are associated with particular alleles in the HLA system (37). Interestingly, the site on chromosome 14 (14q22-24) where we localized an HSP7O gene also corresponds to a fragile site (38). While we do not know the significance of these correlations, it seems important to study expression of heat-shock proteins in cells derived from translocation chromosomes, possibly involving the HSP7O locus, and in various disease states.

A protein with biochemical characteristics similar to HSP70 has been shown to copurify with microtubules from rodent and 
human brain tissues $(39,40)$. The mRNA for this protein hybridizes to a Drosophila HSP70 gene. This is consistent with the finding that bovine uncoating ATPase, isolated from the brain, is closely related to HeLa HSP70. The association of HSP70 with chromosome 21 is of particular interest because of the specific 8;21 translocation seen in acute leukemia (41) as well as the involvement of chromosome 21 in Down's syndrome. Interestingly, a microtubule-associated protein of approximately $70 \mathrm{kd}$ is expressed at increased levels in brain tissue from patients with Down's syndrome (40).

HSP70 has been implicated to function in a variety of cellular pathways, ranging from a "protective" role in response to stress, to replication/repair in cell proliferation $(4,12,13)$. Consequently, the regulation of HSP70 gene expression is likely to be complex. Thus, it may not be surprising that the chromosome 21 HSP7O sequence has diverged, at least at the nucleotide level, from the 6 and 14 sequences, although regulation of expression and the size of the proteins appear to be the same.

Expression of heat-shock genes may be induced by stimuli other than heat-shock itself. In mammalian cells, for example, these genes may be induced by heavy metals and arsenite $(1,3,42)$, the adenovirus Ela $13 \mathrm{~s}$ gene product (6), expression of a rearranged c-myc gene (8), and serum stimulation (4). The upstream regulatory sequences responsive to heat shock differ from those sequences responsive to serum stimulation for a single heat-shock gene (4). This raises the possibility that heat-shock genes are not functionally equivalent, but that a particular gene may be induced only by a subset of stimuli which elicit the heat-shock response. One can envisage, at one extreme, multiple $H S P 70$ genes, each responsive to distinct stimuli. At the other extreme is a single $H S P 70$ gene with multiple regulatory elements. Neither of these possibilities is completely tenable as a result of our finding that at least three distinct HSP7O loci are responsive to heat-shock induction. Identification of hybrid cell lines which contain only one or more of the members of this multigene family will be useful in examining these hypotheses.

\section{ACKNOWLEDGMENTS}

This study was supported by grants from the Camille and Henry Dreyfus Foundation, the Leukemia Foundation, and National Institutes of Health (HD-02080, HD-17449, GM32840). G. Harrison holds an NIH postdoctoral training grant HD-07197. H. Drabkin is supported by an NCI clinical investigator award K01CA01717, and gratefully acknowledges support from the Kyle Dudley Foundation and the Cancer League of Colorado. B. Wu held a PHS postdoctoral fellowship (T32GM07123) at the University of Michigan and is a Special Fellow of the Leukemia Society of America at Northwestern University. We thank Barbara Lamb for technical assistance, and Dr. David Patterson for his support. This is ERICR contribution No. 682.

\section{LITERATURE CITED}

1. Lindquist, S. (1986). Annu. Rev. Biochem. 55:1 151-1191.

2. Schlesinger, M.J., Ashburner, M., and Tissieres, A. (eds.). (1982). Heat Shock: From Bacteria to Man, (Cold Spring Harbor Laboratory, Cold Spring Harbor, New York).

3. Welch, W.J., Garrels, J.I., Thomas, G.P., Lin, J.J.-C., and Feramisco, J.R. (1983). J. Biol. Chem. 258:7102-7111.

4. Wu, B.J., and Morimoto, R.I. (1985). Proc. Natl. Acad. Sci. U.S.A. 82:6070-6074.

5. Nevins, J.R. (1982). Cell 29:913-919.

6. Wu, B.J., Hurst, H.C., Jones, N.C., and Morimoto, R. (1986). Mol. Cell. Biol. 6:2994-2999.

7. Kingston, R.E., Cowie, A., Morimoto, R.I., and Gwinn, K.A. (1986). Mol. Cell. Biol. 6:3180-3190.

8. Kingston, R.E., Baldwin, A.S., and Sharp, P.A. (1986). Nature 312:280-282.

9. Ho, Y.-S., Galos, R., and Williams, J. (1982). Virology 122:109-124.

10. Imperiale, M.J., Kao, H.T., Feldman, L.T., Nevins, J.R., and Strickland, S. (1984) Mol. Cell. Biol. 4:867-874. 
11. Ruley, E. (1983). Nature 304:602-605.

12. Kao, H.-T., Capasso, O., Heintz, N., and Nevins, J.R. (1985). Mol. Cell Biol. 5:628-633.

13. Milarski, K.L., and Morimoto, R. and (1986). Proc. Natl. Acad. Sci. U.S.A. 83:9517-9521.

14. Pinhasi-Kimhi, O., Michalovitz, D., Ben-Zeev, A., and Oren, M. (1986). Nature 320:182-185.

15. Ullrich, S.J., Robinson, E.A., Law, L.W., Willingham, M., and Appella, E. (1986). Proc. Natl. Acad. Sci. U.S.A. 83:3121-3125.

16. Craig, E.A., Jacobsen, K. (1984). Cell 38:841-849.

17. Holmgren, R., Livak, K., Morimoto, R., Freund, R., and Meselson, M. (1979). Cell 18:1359-1370.

18. Ingolia, T.D., Slater, M.R., and Craig, E.A. (1982). Mol. Cell. Biol. 2:1388-1398.

19. Lowe, D.G., Fulford, W.D., and Moran, L.A. (1983). Mol. Cell. Biol. 3:1540-1543.

20. Mues, G.I., Munn, T.Z., and Raese, J.D. (1986). J. Biol. Chem. 261:874-877.

21. Wu, B.J., Hunt, C., and Morimoto, R.I. (1985). Mol. Cell. Biol. 5:330-341.

22. Chappell, T.G., Welch, W.J., Schlossman, D.M., Palter, K.B., Schlesinger, M.J., and Rothman, J.E. (1986). Cell 45:3-13.

23. Drabkin, H.A., Bradley, C., Hart, I., Bleskan, J., Li, F., and Patterson, D. (1985). Proc. Natl. Acad. Sci. U.S.A. 82:6980-6985.

24. Seabright, M. (1971). Lancet 2:971-972.

25. Schested, J. (1974). Humangenetik 24:55-58.

26. Khan, P.M. (1971). Arch. Biochem. Biophys. 145:470-483.

27. Gusella, J., Varsanyi-Breiner, A., Kao, F.T., Jones, C., Puck, T.T., Keys, C., Orkin, S., and Housman, D. (1979). Proc. Natl. Acad. Sci. U.S.A. 76:52395243.
28. Southern, E.M. (1975). J. Mol. Biol. 98:503-517.

29. Harper, M., and Saunders, G.F. (1981). Chromosoma 83:431-439.

30. O'Farrell, P.H. (1975). J. Biol. Chem. 250:40074021.

31. Laskey, R., and Mills, A. (1974). Eur. J. Biochem. 56:335-341.

32. Vermaelen, K., Michaux, J.-L., Louwagie, A., and Van Den Berghe, H. (1983). Cancer Genet. Cytogenet. 10:125-131.

33. Nagarajan, L., Louie, E., Tsujimoto, Y., Ar-Rushdi, A., Huebner, K., and Croce, C.M. (1986). Proc. Natl. Acad. Sci. U.S.A. 83:2556-2560.

34. Servenius, B., Gustafsson, K., Widmark, E., Emmoth, E., Anderson, G., Larhammar, D., Rask, L., and Peterson, P.A. (1984). EMBO J. 3:32093214.

35. Trowsdale, J., Lee, J., Carey, J., Grosveld, F., Bodmer, J., and Bodmer, N. (1983). Proc. Natl. Acad. Sci. U.S.A. 80:1972-1977.

36. Sutherland, G.R., Jacky, P.B., Baker, E., and Manuel, A. (1983). Am. J. Hum. Genet. 35:432-437.

37. Ryder, L., Svejgaard, A., and Dausset, J. (1981). Annu. Rev. Genet. 15:169-187.

38. Barbi, G., Steinbach, P., and Vogel, W. (1984). Hum. Genet. 68:290-294.

39. Lim, L., Hall, C., Leung, T., and Whatley, S. (1984). Biochem. J. 224:677-680.

40. Whatley, S.A., Hall, C., Davidson, A.N., and Lim, L. (1984). Biochem. J. 220:179-187.

41. Rowley, J.D. (1984). Cancer Res. 44:3159-3168.

42. Johnston, D., Oppermann, H., Jackson, J., and Levinson, W. (1980). J. Biol. Chem. 255:69756980 . 